\title{
GRAIN DESTRUCTION BY INSECTS
}

\author{
By DR. A. D. IMMS, F.R.S.
}

$\mathrm{T}$ HE Department of Scientific and Industrial Research has recently published a report* dealing with the infestation of stored grain by insect pests. The survey which it describes was undertaken at the request of the grain trade and with its help and assistance towards the cost. The survey was carried out by the Department of Zoology and Applied Entomology of the Imperial College of Science under the direction of Prof. J. W. Munro. In order to main. tain proper liaison with industrial concerns a Standing Conference was set up, under the chairmanship of Mr. W. McA. Gracie of the L.N.E.R. Co., to act as a consultative body. A Technical Consultative Panel, representative of many aspects of the problem, also established to make this knowledge available for the benefit of the investigation. Also, in order to assist the scientific workers engaged on the survey, a Grain Infestation Survey Committee was set up under the chairmanship of Sir Edwin Butler.

The field work of the survey has lasted about a year. Its most important result is the demonstration that infestation occurs throughout all the industries producing, housing, transporting, trading in, manufacturing, or using cereals and cereal products. No single industry, therefore, is in a position to accuse another as being the source of the prevailing evil. Compared with the elaborate series of processes used for the cleaning, conditioning and refining of flour, the prevailing methods of storage are almost crude.

The major problems appear to be the regulation of humidity and temperature. Until the causes of the rise in these two factors, as affecting stored grain, are better understood, effective regulation is not attainable. This aspect of the subject is a complex one and one which involves time for its solution. Meanwhile palliative measures for reducing and controlling infestation need to be considered. The survey has proved its value in recognizing and defining the main problems that need to be tackled.

" "Report on a Survey of the Infestation of Grain by Insects" (London: H.M. Stationery Office, 1940). 1s. $3 d$.
Good ventilation, general cleanliness, segregation of infested consignments and other simple methods of control have yielded results of value. Hygienic measures alone, however, will not provide sufficient control while heavily infested imported cereals and cereal products are brought into Great Britain.

The problem of insecticidal treatment comes to the fore ; but there are real difficulties and disadvantages involved by their application. The importation of infested grain, as is continually going on, offers little encouragement to the dock authorities to provide modern hygienic transit vehicles and storage capacity. Also, unless these conditions are available it is un. reasonable to expect the exporters to ensure freedom of their cargoes from infestation. In other industries the question whether the importing or exporting parties shall take first action has resulted in a stalemate except in one section of the dried-fruits industry. Timely measures by the Board concerned have resulted in a wholly negligible infestation of Australian dried fruits on the home market during the past five years. The way is thus pointed towards the reduction of one of the major evils of grain infestation.

The insects infesting grain are not natives of the British Isles: they cannot live and breed in our climate in the open, but only in barns, granaries, warehouses, mills, etc. The links in the chain of distributing infestation begin with the arrival of vessels from overseas and go from them to dock premises, vehicles and containers, and so to mills, merchants, breweries, maltings, farms, etc. The report has done good service in stressing the risks and formulating the problems that have to be met at a time when food conservation is of paramount importance. Also, as a beginning, the recognition of proper cleanliness and the separation of infested from clean grain are steps in the right direction. Since there is a whole chain of circumstances requiring control we have to bear the burden of neglect of applied biology at a time when the nation is facing its greatest crisis.

\section{EARLY EXPLORERS OF SOUTHERN SOUTH AMERICA FROM THE UNITED STATES* \\ By Colonel Lawrence Martin, Division of MaPS, Library of Congress}

$\mathrm{I}^{\mathrm{N}}$ October 1829, Capt. Nathaniel Brown Palmer, who had discovered the mainland of Antarctica nine years earlier, sailed from New York in the brig Annawan and Capt. Benjamin Pendleton sailed from Stongington, Connecticut, in the brig Seraph. With them travelled five scientific investigators, Dr. James Eights of Albany, N.Y., Dr. John Frampton

* Abstract of a paper presented to Section VIII (History and Geography) of the Eighth American Scientiflc Congress.
Watson of Philadelphia, Pa., Mr. Jerimiah N. Reynolds of Wilmington, Ohio, and two associates whose names are not known. These five were, as it seems, the first persons from the United States of America who carried out scientific investigations and inland explorations on the continent of South America. The captains of the two brigs independently explored the waters, largely uncharted, between South America and Antarctica. 